\title{
Assessing Perceptions and Practices of Continuous Assessment in English Focus EFL Writing Classes: Secondary School EFL Teachers in Focus
}

\author{
Minwuyelet Andualem Desta $^{1}$ \\ ${ }^{1}$ Debre Tabor University, College of Social Science and Humanities, Department of English Language \\ and Literature, Ethiopia \\ Correspondence: Debre Tabor University, Ethiopia. \\ Email: minwuye2008@gmail.com
}

Received: June 12, 2019

Accepted: August 20, 2019

Online Published: September 1, 2019

doi: 10.23918/ijsses.v6i1p22

\begin{abstract}
The purpose of this study was to assess perceptions and practices of continuous assessment in English focus EFL writing classes. The participants of the study were 5 teachers and 120 students at Debre Tabor secondary and preparatory school. Multiple instruments that included questionnaire, interviews, observation, and document analysis were used to gather data. The findings indicated that the grade 9 EFL teachers didn't have positive perceptions, and they didn't properly practice CA in their school. Although there are various assessment techniques in assessing writing skills, a few of them were only practiced in the writing classes, and, with regard to the provision of feedback, teachers did not properly provide feedback to students in teaching and learning of writings. Besides, there was a gap in practicing $\mathrm{CA}$ in writing classes is that, lack of teachers' perceptions on CA, large class size, shortage of time, and lack of teachers' materials/manuals and the like. Finally, it was recommended that teachers \& students be given training on $\mathrm{CA}$, and the concerned bodies provide the availability of prepared materials, and should frequently organize work shop for serving teachers on the perception \& practice of CA for its effective utilization in school.
\end{abstract}

Keywords: Feedback, Continuous Assessment, Continuous Assessment Techniques, Perceptions, Practice

\section{Introduction}

\subsection{Background of the Study}

Education is the vital role for development. In history, those who have developed in their economy gave prominent emphasis for all subjects' education. Here, English language plays a very important role in various aspects of life globally. Many countries give priority for the teaching and learning of English, and it is hence, taught as ESL and EFL in educational system of different countries (NIED of Namibia, 1999). In the Ethiopian educational system, for example, the teaching of English as a subject begins at the elementary level, and it is a medium of instruction at higher levels (MOE, 1994). Although English has been given such a great position in the Ethiopian educational system particularly, in the English language teaching \& learning process, the English language competence of students is unsatisfactory for their level (Teshome, 2001). 
Poor performance of students in the English language attributed to a variety of factors; like teachers teaching methodology, quality of teacher training, quality of curricular materials, the evaluation process, lack of continuous professional development (on job training), and teachers' and students' attitude towards the subject are some of the factors that affect the performance of students (Richards \& Rogers, 2001; Cross, 1995). In striving to assure quality education particularly, in teaching \& learning of the English language, emphasis on assessment is indispensable. As stated in Educational Training Program (1994), the actual task of practicing the new curriculum in teaching \& learning of the English language at any school level, requires continuous assessment as part of the curriculum in general and the instructional process in particular. To understand this, the role of teachers is paramount importance. Goodrum et al. (2005) ideally argued that the practice of continuous assessment at the secondary school levels is the product of teachers' understanding as one component. Since, without having sufficient awareness on CA, it is difficult to effectively practice it in the classroom.

Although continuous assessment has been practiced in the English language teaching and learning process, the researcher's experience and practical observation in the schools shows that teachers and the students seem to have put doubt on the effectiveness of this procedure. That means, it seems that teachers contradict about the idea of CA \& techniques they encountered while striving to apply it in their writing classes. This is because the students were found to be deficient in their writing skills; the texts (i.e. essays, paragraphs, and summaries) composed by the students were found to exhibit inadequate content, disorganization, lack of focus and use of incoherent sentences with serious spelling and syntax errors. This is what makes continuous assessment different/ unique in writing skills from other content areas/ skills such as reading, speaking etc. (Brown, 2004). The current study mainly aimed at perceptions and practices of CA in English focus EFL writing classes, among grade nine EFL teachers, particularly at Debre Tabor secondary and preparatory school.

\subsection{Statement of the Problem}

Assessing the English language writing skill has been an important part of language testing in both large scale assessment settings and in small scale classroom based assessment. There are different forms of assessing students' writing ability in EFL classes. Among them, continuous assessment is student evaluation system that operates at a classroom level and is integrated with the instructional process (Curzon, 1990).

Assessing students writing skill in the English language teaching \& learning process has a lot of benefits. Concerning this, Ellington and Early (1997) said that continuous assessment in the writing skills teaching \& learning process is carried out on an ongoing basis while students are actually working their way through a course to improve their own writing skills. In our case, however, CA is widely under the system of any school level of our country to realize the fact that underpinned these concepts.

The main factor that ignited the researcher to focus on assessing challenges and perceptions of EFL teachers in practicing CA in English focus EFL writing classes is that, the researcher's experience. As it has already been mentioned, that Debre Tabor is one of the secondary schools in the Debre Tabor town administration, which has been using CA for the last few years. However, its practice has been twinkling. As one of grade nine EFL teachers in the school, the researcher shared experiences with his colleagues in the department. Hence, he observed how CA was practiced in the mentioned school particularly in grade 
nine EFL writing classes. The way that grade nine EFL teachers of the school were practicing CA contradicted with what is said to be appropriate way of administering. Here, the researcher repeatedly observed in the school experience sharing program that many of the mentioned school grade 9 EFL teachers did not assess the students through integrating various CA techniques completely within the teaching and learning in an ongoing way.

In addition, as the researcher confirmed in his experience, almost all of the mentioned school grade $9 \mathrm{EFL}$ teachers considered continuous writing assessment as tests given at different intervals, mid-term exam and final exam. These prominent factors inspired the researcher to look into this problem exhaustively. Moreover, various researches both in Ethiopia and abroad conducted a study on the challenges, and practices of CA in language learning and teaching in different institutions at different levels. As a result, they came up with a variety of recommendations in line with varied problems of the institutions. For example, a research which was conducted by Kapambwe (2010), Mebea (2008), Tefera (2014), and the like. Even though many studies had been conducted about CA on different aspects at different time in the EFL classes at the primary \& secondary school level in general, as far as the knowledge of this researcher is concerned, studies had not focus on any connection concerning the learners' writing skills of the English language. That means, these studies missed in conducting EFL teachers' perceptions and practices of continuous assessment in the EFL classes specifically, in the writing classes.

Hence, the presence of the gap of the study in secondary school of grade nine writing skill, particularly at the mentioned school is unquestionable to be investigated. Besides to the observed problems, this unquestionable gap highly motivated the researcher to conduct the research on this topic. Therefore, the current study mainly focused on assessing perceptions, and practices of CA in English focus EFL writing classes at grade nine EFL teachers. Seeing that assessing writing skill on this grade level, therefore, needs to be treated with great care, attention, and respect to enhance learners' future writing progress.

\subsection{Objectives of The Study}

\subsubsection{General Objective}

The general objective of the study is to assess perceptions and practices of continuous assessment in English focus EFL writing Classes, among grade nine EFL teachers of Debre Tabor secondary and preparatory school

\subsubsection{Specific Objectives}

Specifically, this research intends to:

- Assess EFL teachers' perceptions towards continuous assessment.

- Assess how EFL teachers practice CA in writing classes;

\subsection{Research Questions}

Based on the problem stated and the objectives outlined above, the study tried to answer the following research questions:

- What are the EFL teachers' perceptions in practicing CA in EFL writing classes? 
- How do EFL teachers practice CA in writing classes?

\section{Materials and Methods}

\subsection{The Research Design}

In this study, descriptive survey research design which applies quantitative and qualitative methods of data collection (mixed approach) and analysis was employed because it is applicable to obtain information about teachers' perceptions and practices of continuous assessment in English focus EFL writing classes. Kothari (2004) stated the major purpose of descriptive survey is description of the state of affairs as it exists at present. According to this scholar, the main characteristics of descriptive survey enable the researchers to come up with what has happened or what is happening. And the rationally why mixed approach was employed is that it enabled the researcher to see the issue under study both from qualitative and quantitative perspective. And the nature of the problem and the research objectives invited the researcher to use this research method.

\subsection{Population and Sampling Techniques}

In the Amhara National regional state particularly, in south Gondar Zone, there are twelve towns at woreda level. From those, Debre Tabor town was selected purposively for its ease of accessibility of information for the researcher. There are three secondary and preparatory schools in Debre Tabor town from which the researcher selected Debre Tabor secondary and preparatory school purposively to make the study more manageable and complete within the available time. There were five grade nine EFL teachers (four males $\&$ one female) at Debre Tabor secondary and preparatory school in this year. The total number of Grade 9 student population including EFL teachers in the selected school were 1207. Thus, the target populations for the current study were all grade nine English language teachers, and the sample grade 9 students of Debre Tabor secondary and preparatory school.

Based on this fact, five grade nine English language teachers were taken for this study by comprehensive sampling as they are available in the school. Since a number of teachers in the school are manageable to take the sample as comprehensive. Regarding students' participation, there were 549 males and 653 females, totally 1202 students in the school in 17 sections in this year. The rationally why the students were included as target population is that to see the teachers practice of CA in writing classes. Kumar (2006) pointed out that, in a study the sample size should be selected $10-20 \%$ of the total population. Thus, Out of the total grade 9 students mentioned before, $10 \%$ that is 120 students were selected from section A - P equally by considering males \& females ratio through Lottery method, as they are in the same class under the same school curriculum. Because, each member of the sample had an equal chance of being selected as the study participants.

\subsection{Data Collection Instruments}

The instruments used to collect data for the study were interviews, questionnaires, document analysis and, classroom observation. These instruments were selected because of their suitability for gathering important data for the study. Each of these instruments is briefly described below. 


\subsubsection{Interview}

To the current study, unstructured interviews were conducted by the researcher for five grade 9 EFL teachers who were teaching at Debre Tabor secondary and preparatory school. Because, unstructured interviews were more flexible to collect the data for the current study as needed. Some of the interview questions were developed by adapting items from Hilemariam (2016) \& Sileshi (2007) and the remaining interview questions were developed by the researcher through taking insights from the objectives of the study and literature concerning all the research questions listed out in chapter one.

Moreover, the purpose of interview was to know perceptions of teachers on CA, challenges during practice of CA in writing classes, and how often they practice it. Besides, techniques of CA teachers use, and their feedback provision during practice of $\mathrm{CA}$ in writing classes. Thus, all the teachers were interviewed as well.

\subsubsection{Questionnaire}

In the current study, to get additional information to the data obtained from the teachers through the interviews, questionnaires were used as data collection instruments and were designed to collect relevant data from the sample students of the school. The questionnaire items were developed through adapting items from Takele Amenu (2012) and Hilemariam (2016) and through taking insights from the objectives of the study and literature. To gather the important data for the current study, the close ended questionnaires/ items which are framed in rating scale type with five options (always, usually, sometimes, rarely, and never) were developed for the sample students. Since, the purpose of students' questionnaire is to see how their teachers practice/ apply continuous assessment in the EFL writing classes.

\subsubsection{Document Analysis}

Document analysis is used as descriptive research, current documents and issues are the foci. In the current study, in addition to the information obtained from the respondents with regard to the practice of continuous assessment in the writing classes, this instrument was conducted (Kumar, 1996). Thus, this instrument was designed to see whether or not EFL teachers use different assessment techniques to collect assessment information. The purpose of developing this instrument was to see the documents used by the EFL teachers such as teachers' assessment report/ mark lists, student's notebooks, lesson plan and tutorial given formats and other relevant documents so as to see the practice of CA in the writing classes with evidences.

\subsubsection{Observation}

Observations are important tool that can be employed in descriptive research and other qualitative research types for gathering genuine and pertinent data on teachers' and students' behaviors in the actual setting (Kumar, 1996). In the current study, the researcher used this data gathering tool as supplementary instrument to collect the available information for the study. Accordingly, the classrooms of the teachers were observed for three days each for 40 minutes to check/ to triangulate whether what the teachers' and students' responses to the questionnaires and interview questions match what they actually did in the writing classes. 


\subsection{Data Collection Procedure}

In the course of collecting data for the current study, all the necessary procedures were followed. First, the researcher asked permission from the school principal and explained the purpose of the study before conducting those instruments. Accordingly, after getting permission from the school principal, the researcher observed teachers' writing classes three times each at the different time.

Then after holding the teachers' classroom observations, the interview was held for all grade nine English language teachers about their challenges while practicing continuous assessment in the EFL writing classes and how often they practice it. Besides this, their feedback provision, and techniques teachers use during the practice of CA in writing classes were in focus. Thirdly, next to the teachers' interview, the questionnaires were distributed for grade nine sample students of the school to see how their teachers practice $\mathrm{CA}$ in their writing classes. Finally, in addition to the information obtained from the respondents from the interview and questionnaires with reference to the practice of continuous assessment in the writing classes, document analysis related to the study was conducted.

\subsection{Methods of Data Analysis}

To the current study, the researcher used mixed method (data were analyzed through both quantitative \& qualitative methods) to see the issue under study both from quantitative and qualitative perspective. Concerning these, Kumar (2006) stated out that, quantitative research method helps to analyze data which were quantitative in nature, whereas qualitative research method is used to analyze those data which were not quantitative in nature.

The responses of close ended items of the questionnaires were analyzed, and described quantitatively percentages and mean values. These statistical tools are important for this study because they provide information about the average participants score on a measure. However, the analysis of the data collected using the interview, document analysis and observation items were analyzed using qualitative method of data analysis through using narrative form and in an interpretive manner.

\section{Results and Discussions}

\subsection{Introduction}

This chapter deals with the analysis and discussion of the data collected from subjects to seek answers for the basic research questions raised in the statement of the problem. The primary purpose of this study was to assess challenges and perceptions of EFL teachers in practicing CA in English focus EFL writing classes, among grade nine EFL teachers. Accordingly, 120 grade nine students responded to the questionnaires and the five EFL teachers responded to the interview, document analysis, classroom observation as a sample were assumed to be adequate for the analysis. The analysis was made in terms of the basic research questions raised in the first chapter of the study. 


\subsubsection{Results of the Study}

\subsection{Teachers' Perceptions of Continuous Assessment}

Changing teachers' negative perceptions on CA is used as one component of continuous assessment principles to the well effective practice it in teaching and learning process. In line with this, teachers were asked to give their genuine responses about whether they have positive and negative perceptions towards continuous assessment, its principles and purposes. According to these interviewed teachers, CA should be considered as continuous testing in the teaching and learning of writing.

Accordingly, as Teacher 1 said, "I think continuous assessment is not important for students since it wastes much more time. In fact, it is used to assess learners in general." From the response stated above, it is possible to deduce that there is miss perceptions of continuous writing assessment. Where there is negative understanding of the principles and purposes as needed; there might be misled from the intended objectives. And, the result obtained from document observation also approved that they thought CA as a means to improve students result rather than assisting learners to learn via assessment. In other words, they misuse learners result for condition of pass and fail of learners at the end of semester or year. This revealed that most of the grade nine EFL teachers' perceptions towards CA in contradicted with the idea of continuous assessment.

And, teacher 2, $3 \& 4$ also responded that, although continuous assessment is the continual / progressive evaluation/tests, it is bad for teachers and students all. Because it creates some sort of business and kills time. From these points, it is understood that most of the EFL teachers have negative perceptions towards continuous assessment (which is an integral part of the teaching and learning process).

However, this negative attitude/ idea of teachers towards CA did not tend to agree with the purposes and principles of continuous assessment; since the main purpose of $\mathrm{CA}$ is used to improve learning and to shape the instructional process. Hence, the teachers' response is contradicted with that of the purposes and principles CA. This is one of the indicators that show negative perceptions about the main intention of CA in teaching learning process. And, the data obtained from document analysis also approved that they thought CA as a means to improve students result rather than assisting learners to learn via assessment. This indicated that they perceive continuous assessment that is contradicted with what is said to be the appropriate way of administering.

In addition, the documents of teachers confirmed that their tutorial class did not show that they arrange any tutorial classes for less performing students especially regarding to their writing ability. Obviously, arranging tutorial class for less performing students is one of the principles of CA in the teaching learning process. This implies that teachers have negative perceptions on continuous assessment. Hence, this significantly showed that there is no effective practice of CA in the EFL writing classes. All in all, from the above analysis, it is possible to draw that the grade 9 EFL teachers did not have positive attitude towards CA. This has a negative impact on their practice of CA in the EFL classroom particularly in EFL writing classes. Hence it is necessary for teachers to revise their perceptions of CA. According to Puhl (1997) discussed that opposite ideas to this finding because positive perception of continuous assessment contributes largely to the full development of the learner potential if it is properly communicated. 
In line with this Ellington and Earl (1997) pointed out that continuous assessment enables learners to be asserted in a better situation closely related to the real practice. Teshome (2011) stated teachers should accept continuous assessment as their own for its effective implementation. As to Abiy (2013) teachers and students had a positive attitude towards continuous assessment and they assumed that they would practice it in the teaching learning process to promote students intellectual, emotional and social interaction skills. In addition to this, Brook (2002) stated that teachers' low interest or negative attitudes towards continuous assessment has contributed to poor assessment practice. All these imply that the teachers don't have a full understanding of the concept of continuous assessment and this partly contributes to the poor practice in schools. Linn (2000) cited Birehanu (2004) stated that the new assessment program can succeed only if teachers accept it. If teachers do not have clear understanding of the idea of assessment and if they are not ready to accept the basic philosophy of the program, its implementation will be in question?

The study concluded that the perception of teachers towards continuous assessment was almost neutral \& did not have significance effect on perception of continuous assessment. However, teachers` weekly teaching workload significantly affected on perception of continuous assessment. From the basis of the discussion and findings raised in the study, the researcher has been used to show that teacher perceptions, feelings and ideas can be related to the successful practices of the findings. The findings generated in the study show that greater and more attention needs to be paid to teachers on changing their attitude towards CA to the effective practice in the school at all.

\subsection{Teachers' Practice of Continuous Assessment in Writing Classes}

\subsubsection{Teachers and Students Response towards CA Techniques Employment in EFL Writing Classes}

In line with this interview questions, all the interviewed teachers were asked about continuous assessment techniques they employ in their writing classes. Accordingly, all the interviewed teachers tried to list down one by one as follows. According to these interviewees, the continuous assessment techniques that they frequently practiced in teaching and learning of writing are written tests/exams, quizzes and group work.

As one of teachers responded:

As far as my knowledge is concerned, group work and sometimes pair work are the continuous writing assessment techniques that I employ in my own writing classes to assess learners writing skills in particular (Teacher 1)

And, Teacher 2 also replied that the continuous writing assessment technique that I employ in the writing classes is peer assessment. I sometimes employ individual work to sentences as individual as needed. Regarding to this point, Teacher 3 responded that group work is my continuous assessment technique that by saying the technique may be vary from teacher to teacher. However, as my own, "I employ this technique in the EFL writing classes of the teaching and learning of the English language. This is because to write essays and other writing skills activities, group work is beneficial one to assess learners' achievement. Teacher 4 replied is almost similar to the idea which is replied by Teacher 3.' From this view, one can understand that there was no any attempt to use different writing assessment techniques, 
there were not criteria set and explained to the students. Concerning this teachers' interview, Teacher 5, responded that:

I employ different continuous assessment techniques in my writing classes, such as; pair work, individual work, written exams, group work and the like. However, group work and written exams are the only continuous writing assessment techniques that I mostly practice in the writing teaching process.

From these points which the interviewees revealed above, one can report that the interviewees /EFL teachers use limited number of writing assessment techniques in the EFL writing classes. This could affect the learners' writings achievement. Since, the use of various assessment techniques in the writing classes enables the EFL teachers to assure learners achievement in different directions. This is to mean that the more different techniques used in the writing classes, the better students' mastery of writing skills exist.

Also, with regard to the employment of CA techniques in the teaching and learning of writing, besides to the teachers' interview, grade nine students were asked to give their responses. As to the student respondents, from the students' questionnaire implies that 55\% (66 of 120) of them confirm that most of their EFL teachers always practice group work writing assessment technique in their writing classes. Thus, the following table presents their summary. Regarding Table 2, the researcher requested students that how often their EFL teachers practice continuous writing assessment techniques in their EFL writing classes.

The realizations of CA in writing classes can be accomplished using various techniques. As pointed out in Table 1, item 2, 61(50.83\%) of the respondents responded that their EFL teachers never practice peer writing assessment technique in their own writing classes. Furthermore, the overall mean score $(X=2.59)$ shows that below the expected mean value; since it has less opportunity in practicing process by the EFL teachers in the writing classes 
Table 1: Summary of Students' Response of Teachers employment of Continuous Writing Assessment Techniques

\begin{tabular}{|c|c|c|c|c|c|c|}
\hline Items & & Scales & & & & $(\mathrm{X})$ \\
\hline \multicolumn{7}{|l|}{ 1. Self-assessment } \\
\hline 2. Peer assessment & 5 & 4 & 3 & 2 & 1 & \\
\hline 3. Home work & $\mathrm{F}(\%)$ & $\mathrm{F}(\%)$ & $\mathrm{F}(\%)$ & $\mathrm{F}(\%)$ & $\mathrm{F}(\%)$ & \\
\hline 4. Class work & $13(10.83)$ & $12(10)$ & $62(51.66)$ & $33(27.5)$ & $-(0)$ & 3.01 \\
\hline 5. Written Tests/exams, & $28(23.33)$ & $24(20)$ & $-\left(\begin{array}{ll}0 & \end{array}\right)$ & $7(5.83)$ & $61(50.83)$ & 2.59 \\
\hline Quizzes/ & $29(24.16)$ & $8(6.66)$ & $10(8.33)$ & $67(55.83)$ & $6(5)$ & 2.89 \\
\hline 6. Group projects & $24(20)$ & $13(10.83)$ & $21(17.5)$ & $44(36.66)$ & $18(15)$ & 2.84 \\
\hline \multirow{10}{*}{$\begin{array}{l}\text { 7. Question \& Answers } \\
\text { 8. Observation } \\
\text { 9. Presentation } \\
\text { 10. Individual } \\
\text { projects/Assignments } \\
\text { 11. Writing portfolio } \\
\text { 12. Strategy checklist } \\
\text { 13. Interview } \\
\text { 14.Teacher-student } \\
\text { conference }\end{array}$} & $67(55.83)$ & $35(29.16)$ & $6(5)$ & $7(5.83)$ & $5(4.16)$ & 4.3 \\
\hline & $66(55)$ & $35(0)$ & $26(21.66)$ & $17(14.16)$ & $11(9.16)$ & 3.78 \\
\hline & $21(17.5)$ & $-(19.16)$ & $39(32.5)$ & $10(8.33)$ & $27(22.5)$ & 3.01 \\
\hline & $10(8.33)$ & $23(10)$ & $53(44.16)$ & $31(25.83)$ & $14(11.67)$ & 2.78 \\
\hline & $22(18.33)$ & $12(11.66)$ & $31(25.83)$ & $42(35)$ & $11(9.16)$ & 2.95 \\
\hline & $26(20.66)$ & $14(8.33)$ & $8(6.66)$ & $64(53.33)$ & $12(10)$ & 2.78 \\
\hline & $7(5.83)$ & $10(22.5)$ & $57(47.5)$ & $15(12.5)$ & $14(11.66)$ & 2.98 \\
\hline & $10(8.33)$ & $27(25)$ & $18(15)$ & $43(35.8)$ & $19(5.83)$ & 2.64 \\
\hline & $-\left(\begin{array}{ll}0 & \end{array}\right)$ & $-\left(\begin{array}{ll}0 & 0\end{array}\right)$ & $-(0)$ & $39(32.5)$ & $81(67.5)$ & 1.33 \\
\hline & $17(14.16)$ & $14(11.66)$ & $28(23.33)$ & $17(14.16)$ & $44(36.66)$ & 2.53 \\
\hline
\end{tabular}

N.B (F=Frequency, \%= Percentage, and (Rating scales: Always=5, usually=4, Sometimes=3, rarely=2, Never $=1, \mathrm{X}=$ Mean

As opposed to these students' response, $5.83 \%$ of the respondents reported that their EFL teachers rarely apply peer writing assessment in their writing classes (Table 1, item 2). However, one of the teachers from the interview, pointed out:

The continuous writing assessment technique that I always employ in the writing classes is peer writing assessment technique. I sometimes employ individual work (Teacher 2)

This contradicts with the data obtained from students' questionnaire in Table 1, item 2. This is because most of the student respondents responded that their EFL teachers never practice peer assessment in their writing classes to enhance their own writing skill performance. However, as it is indicated from the interview, the data obtained from the other teachers (i.e. Teacher 1, 3, 4, and 5) tends to agree with the data obtained from students.

Furthermore, as can be observed from Table 1, item 5, $(\mathrm{X}=4.3)$ in the above, the written tests/exams adequately practiced by the grade 9 EFL teachers in the writing teaching and learning of the English language. This is parallel with the data obtained from teachers' documents that consist of learners' mark list and marking system. This indicated that written tests/exams were used frequently as one aspect of continuous assessment in assessing learners in EFL writing classes. 
In the same way, as to the student respondents, in Table 1, item 6, $(X=3.78)$ implies that 55\% (66 of 120) of them confirm that most of their EFL teachers always practice group work writing assessment technique in their writing classes. In line with this, most of the teacher respondents from the interview replied that:

...As far as my knowledge is concerned, beyond the written tests/quizzes, group work and sometimes peer work are the continuous writing assessment techniques that I employ in my own writing classes to assess learners writing skills in general. The reason why I always employ group work writing assessment technique is that large class size and time constraints /work load/ (Teacher, 1).

Here, it is understood that, most of the EFL teachers use group work as a means of solving the work load problems in a frequent way. Since group work assessment technique is one of the productive assessment techniques that can increase students learning and achievement, it should be used regularly and frequently.

Moreover, the result obtained from document analysis has also confirmed that one of the teachers used group work in his lesson plan. From these points which were revealed by students' questionnaires, teachers' interview, teachers' documents analysis and class room observation, the one can draw that most of the EFL teachers use few continuous assessment techniques in the EFL writing classes.

From all these results, it is possible to deduce that the written tests /examination, quizzes and group work were dominantly practiced continuously to assess students' writings in the EFL writing classes whereas, most of other types of writing assessment techniques were neglected. As the result was indicated most of the grade nine EFL teachers gave less concern of using various writing assessment techniques in their writing classes.

\subsubsection{Teachers and Students Response towards CA Provided Feedback in EFL Writing Classes}

With regard to this, all the five EFL teachers were interviewed on how often they provide feedback to their students in the writing classes. Thus, they tried to give their responses as follows. According to interviewees, most of the teachers did not give frequent/timely feedback to the students in the teaching and learning of writing. However, in teaching and learning of writing, providing frequent feedback to the learners enables them that lead to self-correction and improvement.

Teacher 1 replied "I sometimes provide feedback to the students regarding writing skills performance in teaching and learning of the English language, particularly in the writing classes. The number of students and time allotted is not parallel regarding in our school particularly, in grade nine. I run to cover the whole writing lesson because I will be asked if the topics are not covered at all. Thus, the main target is to cover the topics within the given time. In line with this, Teacher 2 replied that actually, I did not give continuous feedback to my students regarding to their writing skill performance, rather I sometimes provide feedback.

Also, Teacher 3 responded,

I sometimes give feedback to the students. It is difficult to provide frequent /continuous feedback. Because there are so many learners in the class, so that it was tire some and it needed hard working and since it was difficult to provide continuous feedback to the writing classes. 
And Teacher 5 also said that I sometimes give feedback because there are large numbers of learners in the class room. To save the time, I did not always give feedback to the students.

This reveals that most of the EFL teachers sometime give feedback to the students in the classroom within the teaching and learning of writing. This way of providing feedback contradict with Scorth (1992) and Corbet \&Anderson (2007) conclusion that states providing immediate/timely feedback more efficient for practical skills.

In addition, the students were asked to give their response regarding the feedback they receive during teachers' practice of continuous assessment in the teaching and learning of writing. And, their response had put according to the following table.

Table 2: Students' Responses regarding to the Feedback they receive

\begin{tabular}{|c|c|c|c|c|c|c|c|}
\hline No & Items & \multicolumn{5}{|c|}{ Scales } & Mean $(\mathrm{X})$ \\
\hline & & $\begin{array}{c}5 \\
F(\%)\end{array}$ & $\begin{array}{c}4 \\
F(\%)\end{array}$ & $\begin{array}{c}3 \\
F(\%)\end{array}$ & $\begin{array}{c}2 \\
F(\%)\end{array}$ & $\begin{array}{c}1 \\
\mathrm{~F}(\%)\end{array}$ & \\
\hline 1 & $\begin{array}{l}\text { My English teacher } \\
\text { provides me feedback on } \\
\text { my writing performance }\end{array}$ & $5(4.2)$ & $27(22.5)$ & $61(50.83)$ & $27(22.5)$ & $-(0)$ & 3.08 \\
\hline 2 & $\begin{array}{l}\text { My English teacher gives } \\
\text { me written descriptive } \\
\text { feedback }\end{array}$ & $10(8.3)$ & $12(10)$ & $84(70)$ & $17(14.16)$ & $-(0)$ & 3.07 \\
\hline 3 & $\begin{array}{l}\text { My English teacher } \\
\text { provides me feedback } \\
\text { which consists of wrong \& } \\
\text { right answers }\end{array}$ & $69(57.5)$ & $24(20)$ & $-(0)$ & $15(12.5)$ & 12(10) & 4.02 \\
\hline 4 & $\begin{array}{l}\text { My English teacher does } \\
\text { not give me any form of } \\
\text { written feedback }\end{array}$ & $1(0.8)$ & $-(0)$ & $-(0)$ & $33(27.5)$ & $86(71.60)$ & 1.30 \\
\hline 5 & $\begin{array}{l}\text { My English teacher } \\
\text { provides me feedback that } \\
\text { indicates my strength and } \\
\text { weakness in my writing } \\
\text { skill }\end{array}$ & $-(0)$ & $34(28.3)$ & $12(10)$ & $61(0.83)$ & $13(10.83)$ & 2.55 \\
\hline 6 & $\begin{array}{l}\text { My English teacher gives } \\
\text { me constructive feedback }\end{array}$ & $17(14.2)$ & $80(66.7)$ & $14(11.66)$ & $5(4.16)$ & $4(3.33)$ & 3.84 \\
\hline
\end{tabular}

N.B (F=Frequency, \%=Percentage and (Rating scales: 5= Always, 4= usually, 3= Sometimes, 2=rarely, $1=$ Never, $\mathrm{X}=$ Mean

Feedback is considered as one basic component of continuous writing assessment particularly, in assessing writing. It is the technique that accelerates students' learning, for it provides motivation for the students if it is done in a continuous manner. In line with this, it is one of the basic questions of the study to see the establishment of feedback in the continuous writing assessment.

Thus, as pointed out in Table 2, item 1,50.83\% of the respondents' response replied that their EFL teachers sometimes provide feedback to their writing performance. In other words, for this aspect in which feedback can be practiced sometimes, since the mean score was in an intermediate point (3.00) which is 3.08 (Table 2 , item 1). 
However, the responses which were obtained from the teachers' interview, shows that the provision of timely/frequent feedback at Debre Tabor secondary and preparatory school was not as such satisfactory. Since, most of the EFL teachers did not properly exercise of giving frequent feedback to their students as it is expected in the practice of continuous assessment in the EFL writing classes. In line with this, as the data obtained from classroom observation indicated that the writing teaching and learning way was almost teacher centered where the learners passively learned. This implies that there was rare chance of continuous assessment feedback exchange between the teachers and the learners or even among the learners within the EFL writing classes.

According to item 2, 67.5\% of the students' response shows that their EFL teachers sometimes give a written descriptive feedback to them (table, 2). In other words, the highest frequency value of item 2, table 2 (81 of 120) shows that the students sometimes receive written descriptive feedback from their teachers. In addition, when we see its mean value of item $2(X=3.07)$ is not more than the intermediate value. Since, such type of feedback is provided/supported as a response of like summative assessment procedures such as formally administered tests or mid exams. Nevertheless, the feedback on continuous assessment procedures in EFL classrooms should be provided within minute's time interval (Angelo \& Cross, 1993).

As pointed out in the above table, item 6, also indicates that 66.66\% (80 of 120) of the English language teachers usually provided constructive feedback to their students (Table 2). Furthermore, the mean value of this item is above the expected mean score $(\mathrm{X}=3.84)$, implies that the grade nine students could have an opportunity to receive constructive way of feedback from their EFL teachers in the writing teaching and learning of the English language. Here, regular feedback can be seen to have a positive impact on students' academic performance, teachers have to exert a great effort for best learning of the students.

Based on the above analysis, regarding the practice of CA in the writing classes, in general, the way that the feedback was given to students is not continuous. The students did not get frequent feedback; this infers there is a partial practice of the continuous assessment activities in the school to assess the students' written work. From this view, one can draw that there were certain gaps which need to be improved.

\subsection{Discussion}

The main purpose of this study was to assess perceptions, and practices of continuous assessment in English focus EFL writing classes. The assessment of EFL teachers' perceptions focuses on continuous assessment in practicing in EFL writing classes.

The assessment of EFL teachers' practice on CA also explores on the techniques, frequency that how often they practice it and the feedback EFL teachers employ in continuously assessing students writings. The effectiveness or ineffectiveness of the practice is related with the challenges; the study explores the major challenges hindering the practice of continuous assessment in EFL writing classes. The results from the analysis of data from interview, questionnaire, document analysis and observations are discussed in line with some empirical findings.

The first research question was intended to identify EFL teachers' perceptions of continuous assessment. The question was raised to find out whether teachers have positive perceptions towards continuous assessment or not. The result obtained through the interview in this regard generally revealed that most 
of grade nine EFL teachers seem to have put doubt that continuous assessment can provide opportunity for assessing learners' writing skills more effectively better than a single terminal exam rather it wastes/kills much more time. From this idea, it is possible to say that EFL teachers have negative attitude towards continuous writing assessment.

The second research question was examining the extent how the EFL teachers practice continuous assessment in their own writing classes. This question was designed to assess the practice of continuous assessment in the EFL writing classes (i.e. frequency that how often teachers practice of continuous assessment in their writing classes, the different assessment techniques that teachers use in the writing classes and the extent that teachers give feedback to students' writings in the EFL writing classes).

As mentioned earlier, the first issue that the researcher investigated was the frequency that teachers' practice of continuous assessment in the teaching and learning of writing. As the results of the study revealed, that teachers' practice of continuous assessment in teaching and learning of writing is minimal. The finding of this study tends to agree/ consistent with the findings of Solomon (2014) that pointed out that there was the improper practice of continuous assessment in the classroom. With regard to this issue, Birhanu (2013) also pointed out that teachers' use of continuous assessment at secondary school is improper (i.e. the proper students' assessments are inadequate).

According to Abiy (2013) findings concluded that continuous assessment was not properly practiced in the schools studied. Coming to the practice of various writing assessment techniques that EFL teachers use to assess the learners' writing skills; Ombe (2014) stated that 'In continuous assessment, the learners' progress in a course, interests, work behavior, adjustment and self-esteem would be assessed through using variety of techniques such as interview, tests, observation, project work, etc. to collect information about the child to reflect the three domains"' (p.90). These multiple techniques can help to improve the reliability of evaluation (Gyankosh, 2013). However, the data collected from student respondents shows that various techniques of continuous writing assessment were nearly ignored from assessing writing skill in grade nine EFL writing classes of Debre Tabor secondary and preparatory school.

And, the last issue that the researcher investigated was about the extent that the EFL teachers give feedback in the teaching and learning of writing. This question was raised since different scholars suggest as feedback is one part of continuous assessment. According to the assessment forum (2008), " feedback should be part of the assessment design, with the process of receiving and responding to feedback in to and made explicit in subsequent learning experiences and grading', (p.2).

As the results of the data gathered from both the questionnaire and interview illustrates that most of the grade nine EFL teachers at Debre Tabor secondary and preparatory school did not provide continuous/frequent feedback to the learners' writings in their writing classes. Besides, they reported that they do not give immediate feedback to the learners. This reveals that there is the dominance of the traditional tests in the school.

\section{Conclusions and Recommendations}

Based on the results and discussions of the findings of the study, it is possible to conclude that grade nine EFL teachers of Debre Tabor secondary and preparatory school did not properly practice continuous 
assessment in the writing classes. This conclusion is drawn depending on the overall findings of the study investigated concerning the two major research questions.

The analysis and discussions of data from all sources entails that almost all EFL teachers have not positive perceptions/out looks towards CA to continuously assess students in EFL writing classes. There are misconceptions that teachers often take for grant in their practice etc. Thus, teachers misuse learners result for condition of pass and fail of learners at the end of the year/semester than to enhance the learners learning in teaching and learning of writing. This entails that negative attitudes teachers on practicing CA in an EFL writing classes.

Regarding to practices of CA, in the teaching and learning writing, the grade nine EFL teachers of Debre Tabor secondary and preparatory school did not continuously employ CA in the EFL writing classes. As it can be seen from the analysis, the involvement of continuous assessment practices in EFL writing classes did not always conform to the expectations at the selected school. It is therefore concluded that continuous assessment was found to be a neglected area of practice. At last, it is recommended that the concerned bodies in collaboration with zone of education office, and the woreda of education office etc. have to organize continuous training for EFL teachers to the effective practice of CA in EFL class room.

Also, the teachers have to be encouraged to conduct intra and inter staff training that emphasis on the application of continuous writing assessment in their school in general either by their school's supervisors, principals or other concerned bodies. And the availability of prepared materials/manuals in the school that would be important for the well effective practice of CA in the EFL classes particularly in writing classes; since these materials enables teachers to update /improve their awareness how the continuous writing assessment would be practiced in the class room. Furthermore, the learners should be involved in the process of CA to enhance the effective practice of continuous assessment in writing classes. Again, the large number of students in a class has to be minimized in order that the teachers can practice continuous assessment in the writing classes and give timely and specific feedback to their students. Thus, the concerned bodies should plan to construct suitable classrooms and set the numbers of students per class as possible.

\section{References}

Abiy Y. (2013). High School teachers' and Students' perception, attitudes \& actual practices of continuous assessment.htt//www.academic journals.org/ERR.

Angelo, T., \& Cross, K. (1993). Classroom Assessment Techniques: A hand book for college teachers. Sanfracisco: Jossey-Bass Publishers.

Brown, D. (2004). Language assessment: Principles and classroom practices. Pearson Longman.

Curzon L. (1990). Teaching in further Educational an outline of principle and practice (4th Edition). London Cassell Educational limited

Ellington, H., \& Earl, S. (1997). Making Effective Use of Continuous Assessment and Portfolios. Available on: file:// apu.cal.ac.uk/cited/ch25:html.56k. Elliott, et al, 2000.Educational Psychology. Von Hoffmann Press, Inc., 3rdEd. USA. 240p.

Hilemariam, K. (2016). The practice of Continuous Assessment in Teaching Speaking Grade Ten students of Beseka Secondary School.' UN published MA Thesis.

Kapambwe, W. (2010). The implementation of school based continuous assessment (CA) in Zambia,' htt://www.academicjournals.org/ERR. 
Kibuna, M. (2013). Tanzania science teachers' practices and challenges in continuous assessment. Unpublished MA thesis.

Kothari, C.R. (2004). Research Methodology: Methods and Techniques. Second Revised Edition. New Delhi: New Age International Publishers.

Kumar, Y. S. (2006). Fundamental of Research Methodology and Statistics. New Delhi: New Age International (P) Ltd.

Ministry of Basic Education and Culture. (1999). Towards Improving CA in Schools: A Policy and Information Guide. Namibia: NIED.

Ministry of Education. (1994). Education and Training Policy. Addis Ababa: St. George Printing Press.

NIED (1999). Improving continuous assessment in schools: a policy and information guide for implementation, Republic of Namibia. Online. Retrieved in July 6, 2014.

Sileshi A. (2007). The Perception and Implementation of Continuous Assessment of EFL Teachers (The Case of Debub Ethiopia Teacher Education College): online retrieved in 16/4/16 from www. Addis Ababa University Institute of Language Studies.

Takele A. (2012). The state of continuous Assessment practice in secondary school of Oromia special zone. Addis Ababa University.

Teshome, D. (2001). Assessment of Pupils Achievements in the Teaching of English Training and Practice in focus. The Ethiopian Journal of Education, 21(1), 25-47.

Yoloye, E.A. (1991). Continuous Assessment. A Simple Guide for Teachers. Ibadan University. 